\title{
«Le Moyen Français» 75
}

\section{Maria Colombo Timelli}

\section{(2) OpenEdition}

\section{Journals}

\section{Édition électronique}

URL : http://journals.openedition.org/studifrancesi/9900

DOI : 10.4000/studifrancesi.9900

ISSN : 2427-5856

\section{Éditeur}

Rosenberg \& Sellier

\section{Édition imprimée}

Date de publication : 1 août 2017

Pagination : 339

ISSN : 0039-2944

\section{Référence électronique}

Maria Colombo Timelli, « «Le Moyen Français» 75 », Studi Francesi [En ligne], 182 (LXI | II) | 2017, mis

en ligne le 01 août 2017, consulté le 05 janvier 2021. URL : http://journals.openedition.org/ studifrancesi/9900 ; DOI : https://doi.org/10.4000/studifrancesi.9900

Ce document a été généré automatiquement le 5 janvier 2021.

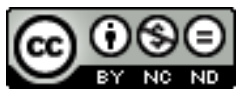

Studi Francesi è distribuita con Licenza Creative Commons Attribuzione - Non commerciale - Non opere derivate 4.0 Internazionale. 


\title{
«Le Moyen Français» 75
}

\author{
Maria Colombo Timelli
}

\section{RÉFÉRENCE}

«Le Moyen Français» 75, 2014.

1 Ce fascicule du «Moyen Français» réunit les textes des cinq conférences plénières données lors du IX ${ }^{e}$ colloque international Christine de Pizan (Université de Louvain, juillet 2015). Soulignons que, si la bibliographie sur Christine est immense, ces articles grâce à des approches renouvelées ou par un encadrement vaste - nous semblent tous contribuer à une meilleure connaissance de l'œuvre et de la personne. La présentation suit l'ordre alphabétique du nom des auteurs. Le volume est inauguré donc par Jacqueline CERQUIGLINI-TOULET, qui explore les modalités, assez nombreuses et diversifiées, par lesquelles Christine «signe» ses œuvres: son nom de baptême, auquel peut s'ajouter son lieu d'origine, sa signature ( $\mathrm{Je} /$ Moy, $\mathrm{C}(\mathrm{h}$ )ristine...»), mais aussi des jeux de mots, anagrammes ou charades, voire allusions au Christ ou à sainte Christine. Femme, chrétienne, et surtout écrivain, Christine affirme résolument sa présence et sa responsabilité d'auteur dans toute son œuvre (Christine de Pizan et le pouvoir du nom, pp. 3-17). Concentré sur un sujet plus particulier, Jean-Claude MÜHLETHALER s'interroge sur la fonction du desir chez Christine et chez les poètes de l'époque de Charles V; sur cette toile de fond, la poétesse occupe une position à part: dans le domaine courtois, elle exprime par l'écrit le désir amoureux des autres, alors que dans le domaine du savoir, l'émerveillement suscite en elle le désir d'apprendre, qui se transforme en littérature (Désir et étonnement: de l'auteur au lecteur. Émotion, écriture et lecture au temps de Christine de Pizan, pp. 19-42). Centrée sur les stratégies adoptées par Christine pour réaliser et légitimer ses prises de parole dans ses œuvres, la contribution de Gabriella PARUSSA met en relief les techniques du dialogisme et de la polyphonie: de nombreuses citations montrent bien comment se construit sa figure autoriale et par quels procédés les idées féministes de Christine s'expriment et s'affirment à l'encontre de l'idéologie masculine dominante (Stratégies de légitimation du discours autorial: dialogie, dialogisme et polyphonie chez Christine de Pizan, pp. 43-65). Les deux dernières interventions portent sur les 
manuscrits de Christine de Pizan. Christine RENo étudie notamment les manuscrits qui portent des marques des possesseurs et/ou des lecteurs anciens: du XVe au XVIII siècle, des signes (manicules ou «Nota»), l'ajout de tables des matières, de titres, incipit, explicit, ainsi que l'insertion du nom de l'auteure, donnent un aperçu de la réception de Christine et de son œuvre à des dates et dans des milieux très divers (La mémoire de Christine de Pizan dans ses manuscrits, pp. 67-83). C'est finalement sur le célèbre «manuscrit de la Reine» (London, BL, Harley 4431) que se clôt ce vaste panoramique: Lori J. WALTERS en examine le contenu en rapport avec les œuvres contemporaines de Christine (Epistre a la reine, 1405; Sept Psaumes allegorisés, 1409; Lamentacion Crhistine, 1410; Livre de Paix, vers 1413) et avec deux sermons de Jean Gerson (1408 et 1413). Les effets d'écho et les reprises d'un texte à l'autre lui permettent d'interpréter l'ensemble du recueil comme un véritable appel à la paix (The Queen's Manuscript as a Monument to Peace, pp. 85-117). 